Article

\title{
Alexander Janneus as High Priest and King: Struggling between Jewish and Hellenistic Concepts of Rule
}

\author{
Vasile Babota \\ Department of Biblical Theology, Faculty of Theology, Pontifical Gregorian University, Piazza della Pilotta, 4, \\ 00187 Roma RM, Italy; babotav@yahoo.com
}

Received: 6 December 2019; Accepted: 9 January 2020; Published: 12 January 2020

check for updates

\begin{abstract}
Josephus refers explicitly to Alexander Janneus in his narratives in both War and Antiquities only as king. Janneus's high priestly office is only implied, and that in a context that is hostile to him (War 1.88//Ant. 13.372). If one looks at Josephus's list of high priests in Ant. 20.242, there he reports that Janneus acted both as king and priest for "twenty-seven years". Was it Josephus who did not want to refer explicitly to Janneus as high priest in his narratives, was this dictated by his source/s, or by some other reason/s? More specifically, why is there a contrast between the narratives and the list? This study adopts source-critical, comparative, and interdisciplinary approach. It also compares Janneus with other rulers from the Hellenistic world with whom he shared many characteristics. However, certain aspects make the Hasmonean high priestly monarchy unique, dictated mainly by theological reasons. That of Janneus is an example of an institutional clash. Josephus was aware of the complexity and controversial aspects surrounding the institution of Hasmonean kingship and its combination with the high priesthood. For various reasons he chose not to identify Janneus explicitly as high priest in his narratives, but rather focus mainly on the royal policy. As an alternative, the Flavian historian drafted an idealized list of high priests in Ant. 20.225-245 that became the basis for developing his theocratic model of government, which—-he probably hoped-could co-exist under the Roman emperor.
\end{abstract}

Keywords: Alexander Janneus; high priest; king; Flavius Josephus; Jewish Antiquities; Jewish War; Aristobulus I; Hasmoneans; Hellenistic high priests and kings

\section{Background}

One of the fields in which Louis H. Feldman was very prolific is the encounter of Judaism with Hellenism. It is to this field that I wish to contribute by focusing on the Hasmonean ruler Alexander Janneus (103-76 BCE). There has been a sudden increase of studies on Hasmoneans in the last fifteen years, in which Janneus received a lion's share. ${ }^{1}$ The principal aim is to look at the way Josephus depicts Janneus in his narratives in both War and Antiquities in comparison with the list of high priests in Ant. 20. Specifically, focus is made on the historian's use of the two official titles of Janneus: that of high priest and king.

The Pythagorean Diotegenes affirmed in his work, 'On the Kingship', that a king has three basic tasks to fulfill: military rule, judging, and care of the gods (apud Stobaeus, Anthology 4.7.61). This

1 See especially, (Nodet 2005; Hanan 2008; Dąbrowa 2010; Seeman 2013; Regev 2013; Babota 2014; Atkinson 2016; Atkinson 2018; Berthelot 2018). Such increase has been prompted by several factors, such as, new results of archaeological excavations, completion of the official publication of the Dead Sea Scrolls (DJD series), the start of the Brill Josephus Project, the growing interest in an interdisciplinary approach, and more. 
concept of kingship was in line with the Seleucid, Ptolemaic, Persian, Babylonian, and Judean/Israelite (i.e., Davidic) kings. Such comprehensive powers also belonged to Janneus/Yannai, although he descended from the Hasmonean high priestly family. On the one hand, Janneus's lack of Davidic pedigree opened his exercise of kingship to challenge. On the other hand, Janneus's combination of two distinct offices, royal and high priestly, was not unique in the Hellenistic world. This was made possible to a great extent, thanks to the continuing decline of the Seleucid kingdom, on the one hand, and the policies of Janneus, on the other. ${ }^{2}$ However, such a model diverges from the Priestly texts of the Torah, which speak only of the cultic role of the high priest and call for his purity at all times. Besides, there was the so-called Law of the King (Deuteronomy 17:14-21; NRSV), which, while it does not specify that this king should be Davidic, nevertheless imposes certain limits on his powers. For example, he should not multiply horses or accumulate riches. Levitical priests, responsible for the custody of the Law, had to make a copy of it for the king so that he would meditate on it day and night. This Deuteronomic law is largely expanded in the Temple Scroll cols. LVI-LXI. Moreover, this document also prescribes that the king consults the high priest concerning whether to go to war or not (11QT LVIII 18-21), which presupposes a diarchy. ${ }^{3}$

\section{The Problem}

Reading the writings of Flavius Josephus (ca. 37-100 CE)—our most important source on the Hasmonean period once 1 Maccabees ends-one soon notes there was some anomaly with Janneus's two highest offices. According to Josephus, Judas Aristobulus I (104-103 BCE) was the first Hasmonean

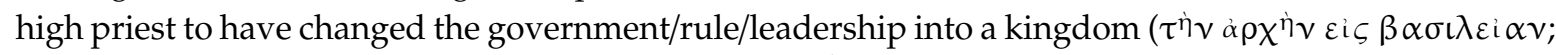
War 1.70//Ant. 13.301; cf. 20.241) and put on a diadem. ${ }^{4}$ At the death of Aristobulus I, "the king's wife", Alexandra Salina, made one of Aristobulus's brothers, namely Janneus, a king (War 1.85//Ant. 13.320).

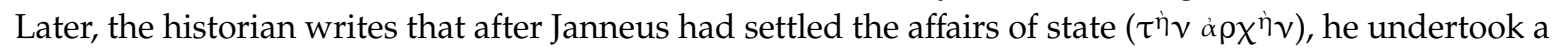
military expedition against Ptolemais. Curiously, Josephus does not speak about the high priesthood of Aristobulus I but instead refers several times to his royal office (War 1.70-85//Ant. 13.301-320). Additionally, in the case of Janneus, the high priestly office is only implied, and that in a context that is hostile to him (War 1.88//Ant. 13.372). ${ }^{5}$ Otherwise, Josephus himself refers to Janneus in his narratives only as king (War 1.85-106//Ant. 13.320-405; see also War 1.113; 5.304; 7.171; Ant. 14.10,36). More telling is Ant. 13.406, where Josephus reports how, at the death of Janneus, the Pharisees claimed to have lost a "righteous king" ( $\delta i \kappa \alpha \iota \zeta, \ldots \beta \alpha \sigma \iota \lambda \varepsilon \dot{v} \zeta)$, and how he had a funeral "more splendid than any of the kings before him" ( $\tau \tilde{\omega} \nu \ldots \beta \alpha \sigma i \lambda \varepsilon \dot{\varepsilon} \omega)$. First, one wonders whom Josephus meant by "kings" before Janneus. Second, in characterizing (the same?) Alexandra, the historian argues that she held control of

2 On the disintegration of the Seleucid kingdom, see (Ehling 2008). The last Seleucid king to have exerted some temporary influence over Judea was Antiochus VII Sidetes (138-129 BCE).

3 On Davidic tradition, see (Pomykala 1995). On how especially the Community behind the 'sectarian' Dead Sea Scrolls-most of which seem to date to the time to Janneus-may have reacted at the combination of both offices in one person, see, fo example, (Collins 2010).

4 The historian seems neither consistent nor specific in his use of the term $\dot{\alpha} \rho \chi \eta$. When speaking of Hyrcanus I (134-104 BCE), father of Aristobulus, Josephus states that the former recovered the high priesthood ( $\tau \dot{\eta} v \dot{\alpha} \rho \chi\llcorner\varepsilon \rho \omega \sigma u ́ v \eta v)$ from his

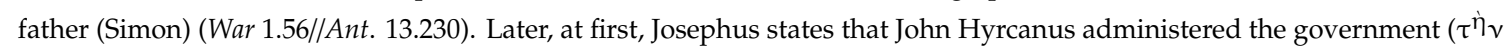

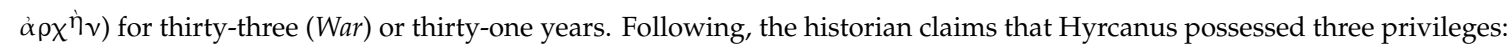

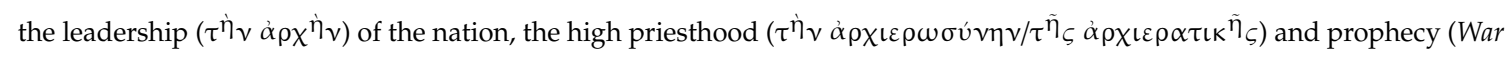
1.68//Ant. 13.299). Here $\dot{\alpha} \rho \chi \eta \dot{~ i s ~ u s e d ~ d i s t i n c t i v e l y ~ f r o m ~ t h e ~ h i g h ~ p r i e s t h o o d . ~ B y ~ c o n t r a s t, ~ e a r l i e r, ~ J o s e p h u s ~ e m p l o y e d ~ t h e ~}$ same term to refer to the rule of Alcimus (Ant. 12.398), whereas his source in 1 Maccabees 7:21 speaks of high priesthood. Elsewhere, the author adopts this term to imply the royal office of the Seleucid (Ant. 13.80-81, 110, 387) or Arabian (13.392) kings. It is worth adding that unlike 2 Maccabees, 1 Maccabees does not use the term $\dot{\alpha} \rho \chi \eta$ to imply the high priesthood.

5 (VanderKam 2004, pp. 318-36), has only noted that there is little one learns about the high priesthood of Janneus but did not discuss why Josephus does not explicitly call Janneus a high priest. 
the government ( $\alpha \rho \chi \eta$ occurs twice in War 1.108). Soon after, we read that Alexandra herself became a queen, while she appointed her son, Aristobulus II, a high priest ( $\dot{\alpha} \rho \chi\llcorner\varepsilon \rho \varepsilon \dot{\alpha} ;$ War 1.109//Ant.13.408).

By contrast, if one looks at Josephus's list of high priests in Ant. 20.224-251, one finds a different tone. ${ }^{6}$ It purports to give an account of the high priests, their total number, and prerequisites for occupying the high priestly office. Unlike in the narratives of both War and Antiquities, in the list, Josephus explicitly states that both Aristobulus I and Janneus held the offices of "priesthood" and "kingship" (20.241-242). Yet when it comes to Janneus, his royal office is listed first. The Flavian historian affirms that Janneus had acted as king and priest for "twenty-seven years". ${ }^{7}$ This contrast with the narratives can hardly be coincidental. Indeed, it seems as if there were an 'official' list of high priests and a separate and different history of them.

Feldman observed that, at least down to Hyrcanus I, especially in Antiquities, Josephus elevates his Hasmonean heroes in the manner of his biblical figures. ${ }^{8}$ It has also been noted that a common characteristic of Josephus' paraphrasing of First Maccabees in Ant. 12-13 is his tendency to use high priestly terminology in places where it does not appear in his source. In fact, for 1 Macc 1:10 13:42//Ant. 12.237-13.214, usage of high priestly terms occurs some 38 times, as compared with 26 times in First Maccabees, or 19 times in Second Maccabees. ${ }^{9}$ Moreover, Josephus composed his works in Rome at a time when the Jerusalem temple with its high priesthood was preserved only in his personal memory and writings. The Hasmonean dynasty itself had ended about a century before the destruction of the temple in $70 \mathrm{CE}$. The question, then, is, was it Josephus who did not want to refer explicitly to Aristobulus I and especially Janneus as high priests in his narratives in both War and Antiquities, or was this dictated by his source/s, or by some other reason/s? More specifically, why is there a contrast between the narratives and the list of high priests in Ant. 20.224-251? We shall consider source-theories first.

\section{Josephus's Sources on Alexander Janneus}

At first, it is necessary to check whether Josephus's use of titles for Janneus could be explained by sources alone. One of Josephus's sources for the Hasmonean period was Strabo of Amaseia (ca. 65-25 CE), whom he mentions some 16 times in Antiquities (none in War). In his Geography, Strabo writes that Alexander [Janneus] was "the first to declare himself king instead of [high] priest" (16.2.40). Most scholars think Josephus-who does not comment on this-was better informed. However, Strabo's testimony appears to indicate that Janneus was perceived by at least some contemporaries as a king, rather than as a high priest or as some combination of the two.

However, many scholars have assumed that, for the Hasmonean period, Josephus relied on the 'Histories' of Nicolaus of Damascus (born ca. 64) more than on any other work. ${ }^{10}$ Some scholars have further suggested that there may be more dependence on Nicolaus in Antiquities than in War. ${ }^{11}$ At least since 14 BCE, and until the death of Herod the Great (4 BCE), Nicolaus spent his academic career at the court of the king. Herod put an end to the Hasmonean dynasty by killing several members who could claim either kingship, high priesthood, or both. In his many volumes dedicated to Herod, Nicolaus tended to appease and portray his patron positively. ${ }^{12}$

On this list of high priests, see (Gussman 2008, pp. 269-87), who underlines its independent historical value and function. Josephus uses the term $i \varepsilon \rho \omega \sigma v ́ v \eta$ when referring to Hyrcanus I, Aristobulus I, and Janneus. By contrast, he adopts the term $\alpha \rho \chi \varepsilon \rho \omega \sigma u ́ v \eta$ for other Hasmonean members: Jonathan, Simon, Hyrcanus II, Aristobulus II, and, indirectly, Aristobulus III. 8 (Feldman 1994, pp. 41-68).

9 (Babota 2014, p. 30).

10 See, among others, (Laqueur 1920, pp. 137-42; Wacholder 1962, pp. 5-6; Stern 1971, pp. 375-94; Schwartz 1983, pp. 157, 162; Feldman 1994, pp. 42-44; Mason 2016, pp. 23-24).

11 See, for example, (Wacholder 1989, pp. 152-72); similarly, (Schwartz 1983, p. 382).

12 See, among others, (Schwartz 1983, p. 162). For a recent discussion of the academic career of Nicolaus, also in Rome after Herod's death, see (Toher 2017, pp. 1-21). 
On the one hand, the extent to which Josephus shaped the excerpts from Nicolaus or other source/s is beyond what we can be sure of. ${ }^{13}$ Even if one accepts that Josephus's source did not refer to Aristobulus I and Janneus as high priests (which is very doubtful), this does not explain why Josephus did not alter his source since he had the freedom to do so (cf. War 1.68//Ant. 13.299 of Hyrcanus I). Furthermore, Josephus has no qualms about stating that Hyrcanus II and Aristobulus II acted both as kings and high priests (Ant. 14.97). However, it is to be noted that both these rulers acted so, already under the watcheye of the Romans.

On the other hand, one would expect that, because Josephus claimed Hasmonean royal descent, he should have been positive about both Aristobulus I and Janneus as founders of the royal dynasty (Life 1-10; Ant. 16.187). This notwithstanding, not only does the historian not refer to them explicitly as high priests; he decides to include sources which portray them in a negative way. Steve Mason is right in stating that "Josephus was not a slave to his sources, but rewrote and shaped the narrative as he saw fit". ${ }^{14}$ Yet this does not fully account for the differences between the list of high priests and the narratives.

There may have been several reasons for Josephus's authorial behavior but it is difficult to judge which one of them was more, or less, important to the historian. First, the learned audience of his time could, in principle, check about Hasmonean rulers in some of the sources Josephus was using. Second, the Flavian historian had to explain why the Hasmonean dynasty brought about Roman intervention in Judea under Pompey (e.g., War 1.19; 1.131-132; Ant. 14.41-47). ${ }^{15}$ Third, he also had to explain why the Hasmonean dynasty came to an end after a "hundred and twenty-six years", and why Herod the Great succeeded them as king (e.g., 13.300; 14.78, 490-491). ${ }^{16}$ Fourth, Josephus may have felt the need to explain why, unlike Herod, the Hasmoneans failed to rebuild the temple (17.162). ${ }^{17}$ Fifth, by this time, Josephus had formulated his "theocratic" view of the Mosaic constitution, which apparently has no place for a native or foreign king (Ap. 2.145-189). ${ }^{18}$ Such position was, to some extent, to be expected for someone writing in Rome at the time. These and perhaps other reasons led Josephus to claim that: "[w]e, however, being of a family closely related to those descended from the Hasmonean kings, and therefore having together the honor of priesthood, have considered it unfitting to say any falsehoods about them, and so we relate their deeds with sincerity and fairness" (Ant. 16.187). ${ }^{19}$

This authorial admission calls into question scholarly approaches that would ascribe everything Josephus writes to his sources. A closer look at the way the historian describes the kingship of Aristobulus I and Janneus shows that it too was shrouded in controversy. Examining how Josephus categorizes these leaders' royal status will help us better understand his attitude towards their high priesthood as well.

\section{Josephus on the Institution of the Hasmonean Kingship}

Before focusing specifically on Janneus, it is deemed necessary to analyze how Josephus perceived the Hasmonean kingship, in general. Meron M. Piotrkowski, who has dealt with what he calls 'anti-monarchic' discourse, posits that Josephus's whole Hasmonean narrative reaches a "climax" with

13 For an attempt to reconstruct pre-Josephus sources, see (Mendels 2005, pp. 3-19). For possible sources used in Antiquities and an interpretation of how Josephus handled them, see (Schwartz 2016, pp. 36-58). Other possible sources for the Hasmonean period include: Eupolemus, Alexander Polyhistor, Strabo of Amaseia, or Josephus's political and literary rival, Justus of Tiberias. See further, (Stern 1974, pp. 157, 262, 265-67; Wacholder 1974, pp. 50-51, 53-57).

14 (Mason 2016, pp. 24-25).

15 On this aspect, see the long analysis by (Sharon 2017, pp. 171-330).

16 Thus, Josephus explains that it was because of internal strife against each other that the Hasmoneans lost their rule $(\delta\llcorner\dot{\alpha} \tau \dot{\eta} v$

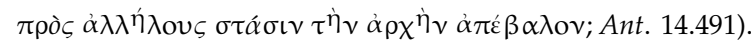

17 It is worth mentioning that Josephus held admiration for his political and literary rival, Justus of Tiberias, who served as secretary of the last Herodian king, Agrippa II Ap. 1.51; see also Life, pp. 336-367). See further, (Rajak 1987, pp. 103-26; Mason 2001, pp. 135-50).

18 For a comment, see (Barclay 2007, pp. 273-75; Gussman 2008, pp. 306-20).

19 Adapted from (Marcus 1963, p. 283). 
Hyrcanus I, who represents the ideal ruler. This is then contrasted with an "anti-climax" focusing on the downfall from Aristobulus I on. After discussing 1 Samuel 8 and some other biblical passages, this scholar concludes that "Josephus ... stands well in the Jewish tradition ... of being suspicious of and opposing kingship". 20

Given our present aim, we will not engage Piotrkowski's arguments here. We note, however, that, in principle, Josephus may have not been that 'anti-monarchic' when discussing the Hasmonean kingship. At first, the Flavian historian seems to hold the Hasmonean royal office in esteem. Not only does he boast of his descent from the royal priestly line; he criticizes both Aristobulus II and Hyrcanus II for having disrespected it. Thus he writes: "[t]he kingship ( bestowed on those who were high priests by birth became the privilege of commoners" —alluding to Herod the Great (Ant. 14.78; see also 14.490-491 where Josephus speaks of the "dignity" of Hasmonean priesthood). It is worth stressing here that, even if Josephus is not explicit on this, Aristobulus I and Janneus are the implied high priests and kings.

It seems as if one of the main problems for Josephus was how to justify the institution of the Hasmonean kingship. Feldman noted how Josephus "significantly, avoids the comparisons of Judah [Maccabee] with King David such as we find in 1 Maccabees", namely, in 2:57. ${ }^{21}$ His observation is especially relevant with regard to the Hasmonean kings. Josephus makes not even an allusion to David when Aristobulus I or Janneus are introduced as kings, and apart from War 1.61//Ant. 13.249, David is altogether absent in his narratives about the Hasmoneans. That Josephus had high regard for David is seen from both his paraphrases of the biblical texts as well as from other passages (e.g., War 5.143; $6.439,644)$. Additionally, when Josephus boasts about the kings of his nation, he names David and Solomon "who subdued many nations" (Ap. 2.132); not the Hasmonean kings.

Another striking aspect is the way Janneus is said to have become king by being appointed by the widow of his brother and self-proclaimed king, Aristobulus I (Ant. 13.320). The role and identity of this woman has received much scholarly attention. Henry St. J. Thackeray wrote that, although "Josephus never expressly says so, it appears certain that, besides the throne, she gave Alexander Jannaeus her hand in marriage". ${ }^{22}$ Drawing the same conclusion, Ralph Marcus affirmed "[t]hat Josephus considered Aristobulus' wife to be identical with Alexander Jannaeus' wife Alexandra is clear from the context and chronology". ${ }^{23}$ More recently, Joseph Sievers has argued that the same Alexandra later (again) became queen at the death of Janneus. ${ }^{24}$ Kenneth Atkinson, however, is of the opinion that "[ $\mathrm{t}]$ he best interpretation of the extant evidence is that Salina Alexandra and the Hasmonean monarch Alexandra are two different women". ${ }^{25}$ One of the main arguments Atkinson adduces is the biblical law, according to which a high priest could not marry a widow (Leviticus 21:14) and that he could not contract a levirate marriage (Deut 25:5-10). The troubled history of the Hasmoneans shows that this may have been the least of their problems. The institution of the Hasmonean high priesthood itself was characterized by several controversial aspects in that Jonathan and his successors adopted a Hellenistic model of high priesthood combined with civil powers. ${ }^{26}$

20 (Piotrkowski 2015, pp. 253, 265).

21 (Feldman 1994, p. 67; van der Kooij 2012, pp. 29-49), argues that 1 Macc 2:54, 57 hint at the priestly and royal rule of Janneus. The author, therefore, dates the book to about $100 \mathrm{BCE}$. This is, of course, possible but requires a more adequate interpretation of 1 Macc 8, which seems to praise the non-royal government of the Romans. Alternatively, one could argue for insertions done in the Greek version.

22 (Thackeray 1927, 42 n. a).

23 (Marcus 1957, 388 n. a).

24 (Sievers 1989, pp. 134-40).

25 (Atkinson 2016, pp. 85-86). The author, however, over interprets the source when he affirms that "Josephus states that the wife of Aristobulus selected the next king and high priest".

26 See (Babota 2014, pp. 285-91). Furthermore, such actions as frequent participation in warfare, torturing and killing each other as well as their inner opposition, entertaining publicly with concubines and heavy drinking (e.g., 1 Macc 16; Ant. 13.380, 398), inner family marriages to save the control of the country and their interactions with the Gentiles, rather demonstrates that most Hasmoneans acted violently in order to preserve themselves in power. The only exception may have been the last Hasmonean high priest Aristobulus III-the grandson of both high priests Hyrcanus II and Aristobulus II. However, 
On the one hand, the fact remains that Janneus was granted kingship from the hands of a widowed woman whom some scholars regard as an acting queen at the death of Aristobulus I. The rise to such power by women was well known in the Hellenistic world, but for Judean history it was a Hasmonean innovation. ${ }^{27}$ On the other hand, unlike several monarchic dynasties of the Hellenistic world, the Hasmoneans did not legitimize their kingship by associating themselves with any divine figures. Nor were they direct successors of a pre-existing national dynasty. In other words, both Aristobulus I and especially Janneus had to create their kingship de novo. No wonder that more than a decade after the death of Janneus, in about $63 \mathrm{BCE}$, his warring sons Aristobulus II and Hyrcanus II are accused by a Jewish delegation before Pompey of unjustly arrogating the kingship to themselves and so overthrowing the "ancestral laws" (Diodorus Siculus 40.2; cf. Jos., War 1.131-132; Ant. 14.41-47). ${ }^{28}$ Josephus offers a less harsh accusation in Antiquities, whereas in War it is missing altogether. A clear denunciation of the establishment of Hasmonean kingship is found also in Psalms of Solomon 17. Since in both cases the accusation is about "kingship", no doubt Janneus is also implied.

To sum up, it emerges that while Josephus claims to have adopted a fair attitude towards Hasmonean rulers, he also makes an effort to tacitly defend the institution of their kingship. This is in spite of several controversies which surrounded it. What, then, were the practical ways in which Janneus promoted and established himself as king and high priest? What were some of the main problems encountered, and how does Josephus address these narratively?

\section{Alexander Janneus in Defense of His High Priesthood and Kingship}

\subsection{High Priestly Office}

Hereditary right to the high priesthood undoubtedly played a significant role in Janneus's apologia. Any attempt by a non-Hasmonean priest to take control of it would have been branded a usurper. The Hasmonean Jonathan came to power in this way, but by that time at least some members of the Oniad high priestly dynasty seem to have withdrawn to Leontopolis in Egypt. Later, it was Herod the Great who executed the last Hasmonean claimants to this office, though he did not himself become a high priest but appointed one. ${ }^{29}$

It should be emphasized that Janneus could exert his authority as high priest, not least, because part of the temple priesthood would support his right to this office. According to Josephus, Hyrcanus I built a tower near the temple where he kept his high priestly vestments; the same was done by other Hasmonean high priests (Ant. 18.91-92). This dress was the symbol of the highest religious authority in Judea. ${ }^{30}$ Control of the high priestly office assured Janneus a degree of control over the temple itself. Control of the temple, in general, had always played an essential role in the policy of any foreign monarch prior to Hasmonean independence. With the destruction of the temple on Mt. Gerizim by Hyrcanus I, probably in 108 BCE, Jerusalem's temple grew in religious and economic importance. This made the religious rule of the expanding Hasmonean state more centralized and effective, at least as far as their Jewish subjects were concerned.

Aristobulus III was appointed high priest by Herod the Great when he was merely only 17 years old, and was soon drowned at the order of the king (Ant. 15.55-56). See further, (Van Henten 2014, pp. 38-42).

27 Some of these rulers include Olympias, Adea Eurydice, Cratesipolis, or Cleopatra VII. See further (Macurdy 2000); see also (Mitchell 2012, pp. 1-21).

28 "During Pompey's stay in Damascus of Syria, Aristobulus [II], the king of the Jews/Judeans, and Hyrcanus [II] his brother came to him with their dispute over the kingship. Likewise, the leading men, more than two hundred in number, gathered to address the (Roman) general and explain that their forefathers, having revolted from the sanctuary, had sent an embassy to the senate, and received from them the leadership of the Jews, who were, moreover, to be free and autonomous, their ruler being called high priest, not king. Now, however, these men were lording it over them, having overthrown the ancient laws and enslaved the citizens in defiance of all justice".

29 See (VanderKam 2004, pp. 394-405).

30 Later on, the high priestly vestments became a real political instrument, first of Herod the Great and his son Archelaus, and then under Romans down to $37 \mathrm{CE}$, when Vitellius-after removing the high priest Caiaphas-placed them back under the custody of the temple priests (Ant. 18.91-95; cf. 20.6-14). 
Ya'akov Meshorer stresses how the Jerusalem temple "was not only the religious center of the Jewish people" but also its "central bank". ${ }^{31}$ It was a source for loans and a debt collector, and had a depository of collective and/or individual goods and donations both from inside Judea as well as from Diaspora Jews. According to Marty E. Stevens it "functioned as an economic institution... in ways similar to other ANE temples". ${ }^{32}$ The Jerusalem temple was, therefore, not only the heart of the religious and economic life of the Jews, but also a potential instrument of political control for both temple and royal officials.

In Ant. 13.372-383, Josephus recounts how, during a Festival of Tabernacles, the crowd revolted against Janneus and pelted him with citrons and wands made of palm branches (see $m$. Sukkah 4.9 for a similar story). They accused him of being unworthy of the high priesthood because of his descent from captives. It could be that Janneus was charged for the same reason as his father, Hyrcanus I (Ant. 13.288-295; cf. the similar story in b. Qidd. 66a, but about Jannai). The sedition ended with Janneus reportedly slaughtering 6000 protesters (Ant. 13.373). The parallel and somewhat sketchy account in War 1.90-98 provides a slightly different version. Most historians associate this event with the military campaign of the Seleucid King Demetrius III Eukerus (97-87 BCE) against Janneus in 88 BCE. This leads to a discussion of the Hasmonean army and the way Josephus handles this unprecedented reality in the history of the Jewish high priesthood.

\subsection{Army and the Question of Mercenaries}

The Hasmoneans were in control of fighters even before Jonathan had acquired the high priestly office in 152 BCE. The Hasmonean army considerably increased by the time of Janneus. In addition to Jewish fighters, already Jonathan and his brother Simon may have started employing mercenaries. ${ }^{33}$ Hiring mercenaries in the Hellenistic world was a widespread phenomenon. ${ }^{34}$ Hyrcanus I is said to have been the first (?) to have maintained mercenaries ( $\mu \iota \sigma \theta 0 \varphi$ ó $\rho \circ)$, probably on a regular basis. Josephus reports how Hyrcanus opened the tomb of King David to extract riches from there, part of which he used to maintain foreign troops (War 1.61//Ant. 13.249). ${ }^{35}$ The practice of hiring mercenaries apparently intensified under Janneus, who reportedly had 8000 (War 1.93) or 6200 (Ant. 13.377) of them. Josephus specifies that these came from Pisidia and Cilicia (War 1.88//Ant. 13.374). ${ }^{36}$ His wife, Queen Alexandra continued the recruitment of mercenaries (Ant. 13.409). ${ }^{37}$

The importance of mercenaries is highlighted also by the reported six-year Jewish revolt. The growing anti-Janneus faction eventually asked Demetrius III to intervene, which he did (War 1.92; Ant. 13.376). Janneus lost his battle while "all" his Greek mercenaries, who demonstrated commitment and faithfulness to him, were slain by the Seleucid army (War 1.93-94; Ant. 13.378). Later, during a banquet, Janneus had some "eight hundred" of those Jews who defected to Demetrius crucified (Ant. 13.380//War 1.97). ${ }^{38}$ Josephus offers a comment here (Ant. 13.380-383). At first, he seems to almost

31 (Meshorer 2001, pp. 73-74). The author also points out that "[f]rom 127/6 BCE onwards Tyrian shekels were the only official coinage acceptable in the Temple as payment of the half-shekel tribute". This period roughly coincides with the time when Hyrcanus I began to strike his own coins. Earlier, (Ariel 1982, p. 284), argued that that "there is every reason to believe that Tyrian shekels would have been current in Jerusalem even without the Temple tax".

32 (Stevens 2006, p. 171). See also (Kerkeslager 1998, pp. 99-225; Goodman 1999, pp. 69-76; Schiffman 1999, pp. 480-96; Lapin 2018, pp. 409-53 (relevant also for the Hasmonean period)).

33 (Babota 2014, p. 126), passim.

34 The following three studies are fundamental: (Griffith 1935; Launey 1950; Chaniotis 2005, pp. 78-101). At least part of the mercenaries was usually accompanied by their families and were often in possession of land. See further, (Loman 2005, pp. 346-65). One wonders how this worked in the Hasmonean Judea.

35 Another part of the riches Hyrcanus I probably used to negotiate the lifting of the siege by the Seleucid king Antiochus VII Sidetes. On this siege, see Jos., War 1.61; Ant. 13.236-249; Diod. 34/35.1.1-2, 4-5.

36 Mercenaries from Pisidia and Cilicia along with those from Galatia were regularly hired by the Attalid kings from the third century BCE onward, see Diod. 18.61.4-5; Polyb. 5.78.5; Livy 42.57.7-9.

37 See the study of (Shatzman 1991).

38 These numbers should not be taken literally, of course. These measures remind those of Antiochus IV against Jews (Ant. 12.255-256) in the prelude to the Hasmonean revolt. 
approve Janneus's actions; soon after, however, he finds himself in need of explaining the nickname by which Janneus was known to his source, namely "Thracian", and so admits that the measures of Janneus were excessive. This account is very probably corroborated by the Pesher Nahum (4Q169) scroll from Qumran. Thus 4QpNah 3-4 I 1-12 alludes to the military campaign of King Demetrius of Yavan (Greece) in Judea at the invitation of the Jews. This document apparently refers to Janneus by the code name "Lion of Wrath" (see also 4QpHos ${ }^{\mathrm{b}}$ [4Q167] 22). ${ }^{39}$ It also may allude to their crucifixion by the "Lion of Wrath", who would "hang men up alive". It is a widespread view that the label "Ephraim" in the DSS denotes the Pharisees as those involved in the anti-Janneus revolt. ${ }^{40}$

The issue of mercenaries surfaces again in the words of the Jewish delegation before Pompey. They accuse the Hasmoneans of having established their kingship "by means of a horde of mercenaries

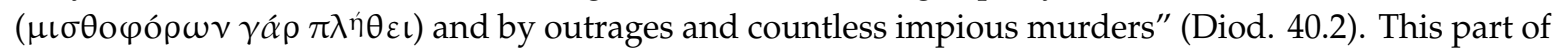
the accusation is strikingly missing in Josephus's Ant. 14.41, who likely wanted to minimize the role of mercenaries in establishing and maintaining the Hasmonean kingdom. ${ }^{41}$ The discussion of the army is also relevant for our understanding of the expansion of the Hasmonean borders, which was another unparalleled phenomenon in the Second Temple high priesthood.

\subsection{Expansion of Territories and Cessation of Diplomatic Relations}

The conquests of Hyrcanus I and Aristobulus I included new territories. By the time of Janneus's rule, the Samaritans were only a minor problem. Janneus himself began his rule with bloodshed, initially by eliminating some of the pretenders to the throne within his own family (War 1.85; Ant. $13.323 ; 14.71)$, and later by undertaking several military ventures both offensive and defensive. In this way new inhabitants were added to the Hasmonean domain: non-Jews (e.g., Itureans, Idumeans), territories where Jews were likely a minority (e.g., Transjordan), and/or heavily Hellenized Jewish communities (Northern Galilee, some coastal cities). ${ }^{42}$

The new conquests amounted to much more than the territory controlled by the pre-exilic Davidic kings of Judea. With non-Jewish populations incorporated into the Hasmonean state, such titles as "high priest" or "ethnarch" appear to have not sufficiently addressed this new situation. Conquest of new territories was one of the primary reasons which led to the institution of the Hasmonean kingship. There is reason to suppose that Hyrcanus I may have already considered himself a de facto king, at least in the last years of his rule. The sedition reported by Josephus in War 1.67//Ant. 13.288, which occurred in the final years of Hyrcanus's rule, may have been provoked by his intention to take the title of king.

The institution of Hasmonean kingship also appears to have coincided with the cessation of active diplomatic relations with the Republic of Rome. Probably after 113/112 BCE, Hyrcanus I no longer sought to preserve diplomacy with Rome where several Hasmonean leaders since Judas used to appeal to counter the Seleucid and other foreign influences; nor did Judas Aristobulus I renew it. ${ }^{43}$ Most striking, however, is that during his long reign, Janneus seems to have made no such attempt either, even when he was on the point of losing his kingdom. ${ }^{44}$ Nor does Josephus say that Janneus was ever trying to deal with the Seleucids on any diplomatic level. As can be inferred especially from his coins, the claim of Janneus to kingship was a strong political message that Jews are totally independent and can live on their own. In fact, besides using his army to defend both his offices and assure himself

39 See, for example, (Berrin 2004, pp. 91-99, 105-6; Schiffman 2010, pp. 337-52), who represent the large majority view. However, (Doudna 2011, p. 259), passim, thinks the "Lion of Wrath" here stands for Kittim, i.e., Romans. For a recent discussion, see (Babota 2020).

40 See further, (Babota forthcoming).

41 (Stern 1974, p. 186), following other scholars, suggested both Diodorus and Josephus may have used Theophanes of Mytilene, the assistant of Pompey. Seeing that Josephus refers to Strabo in Ant. 14.37 and not long after in 14.68, that is, just before and after the Damascus episode (14.41-47), it is also possible that Josephus drew on Strabo here.

42 See, for example, (Berthelot 2018, pp. 240-83).

43 See (Seeman 2013, pp. 218-30). For possible reasons behind the "breaking of ties" with Rome, see (Zollschan 2017, pp. 258-69).

44 We should not exclude that opposition groups may have tried to seek support from the Romans even before 63 BCE. 
control also of new territories, Janneus made heavy use of propaganda, too. For the present purpose, we note that while Josephus is tacitly approving the expansionist policy of Janneus, he provides no comment on the cessation of Hasmonean diplomatic relations with Rome.

\subsection{Coins, Bullae, Literature, and Other Propagandistic Channels}

Josephus either did not know or perhaps did not want to mention that his Hasmonean ancestors struck their own coins. After the mint of Antiochus VII came to an end in Jerusalem in or shortly after 129 BCE, starting with Hyrcanus I, Hasmonean bronze coins both imitate and innovate the traditional Seleucid mint. ${ }^{45}$ The following religious symbols are visible on the coins of Janneus: double cornucopiae, scepter, pomegranate (cf. Exodus 28:33; 1 Kings 7:18; Jos., Ant. 3.145), and lily as a symbol of the temple. Like Hyrcanus I, both for his title of high priest (HKHN [HGDL]), as well as for his three variant names (YNTN/YHNTN/YWNTN), Janneus adopted only Paleo-Hebrew. This was a way to stress to his fellow Jews the traditional importance of the ancient office now held by him. At the same time, it was a way of announcing a national revival which had started already under Hyrcanus I. ${ }^{46}$ It is worth noting that the designation heber ha-Yehudim appears on coins of Janneus only with the title of high priest. It has been posited that it may refer to a governmental body in Jerusalem, or that it represents "the entire Jewish people as sovereign body". ${ }^{47}$ For the present purpose, it should be noted that for the non-Jewish populations, the title of high priest—which was a typically religious title-had little or no significance. ${ }^{48}$

Janneus, in fact, is the first attested Hasmonean ruler who struck coins also with the title of king. The following royal symbols are incised: an anchor within a circle/diadem or alone, a star alone, or sometimes inside a diadem or surrounded by dots, a palm branch. Unlike Hyrcanus I, Janneus seems to have not displayed the crested helmet on his coins, perhaps as a way to limit the Greek-Seleucid practice. ${ }^{49}$ The continuous use of these symbols, together with the adoption of the title "king" show that Janneus wanted to imitate other Hellenistic monarchies and perhaps compete with others. ${ }^{50}$ In their influential study, de Calataÿ and Lorber argued that "with few exceptions, royal epithets on coins began to appear only in the second quarter of the second century [BCE], thus more than a century later than what we know from literary and epigraphic sources". ${ }^{51}$ One wonders how this widely spreading practice might have influenced the policy of the coinage of Janneus.

Janneus was also the first Hasmonean to have introduced bilingualism on his coins, namely Paleo-Hebrew and Greek, and in a limited amount, also Aramaic. All three languages are, in fact, used to advertise his royal title. Using Greek-which is predominant-was in line with Seleucid practice, imitated other contemporary Hellenistic states, and was probably better tolerated by the non-Jewish populations within the Hasmonean state. Mention should be made here also of the Greek name of Janneus, namely Alexander, which is well attested on his coins and in literature. ${ }^{52}$

45 See especially (Hoover 2003, pp. 29-40; Hübner 2005, pp. 171-87; Hendin 2008, pp. 76-91). On Janneus's seven types of coins, see (Meshorer 2001, pp. 37-41, 209-17 (with Plates); Shachar 2004, pp. 5-33; Hendin and Shachar 2008, pp. 87-94 (with bibliographies)). For an interpretation of Hasmonean coins with particular emphasis on those of Janneus, see (Regev 2013, pp. 175-223; Schwentzel 2013, pp. 77-92).

46 There is no clear attestation of coins minted by Simon, or before by Jonathan.

47 For the latter suggestion, see (Regev 2013, pp. 186-99), who thinks the Hasmoneans aimed through coins to represent Jewish Diaspora as well.

48 (Berthelot 2018, p. 226), stresses the almost total silence of ancient sources of any destruction of a non-Jewish temple at the hands of the Hasmoneans. This is plausible, also, in the light of hiring foreign troops and integrating them within the Hasmonean permanent army. One can hardly imagine all of them would have completely given up their religion. On the problem of integrating the non-Jewish populations within the Hasmonean Judea, see further, (Berthelot 2018, pp. 283-334; Eckhardt 2013, pp. 308-14, 335-43).

49 See (Meshorer 2001, pp. 36-37). According to Meshorer, pp. 55-57, the menorah was incised only later on the coins of the high priest Mattathias Antigonus.

50 On Hellenistic royal ideologies, mainly Ptolemaic, Seleucid, Attalid, Arsacid, and Antigonid, see (Ma 2003, pp. 177-95). On the coins struck by various Hellenistic monarchies and cities, see the selections by (Hoover 2009, 2010).

51 (de Calataÿ and Lorber 2011, p. 419).

52 See further, (Tal 1987, pp. 1-20). 
Not least, there was in circulation 1 Maccabees, in both Hebrew and Greek, in and probably outside Judea, as well as a 'Chronicle' of Hyrcanus I (cf. 1 Macc 16:23-24). ${ }^{53}$ The aim of this 'official' literature had the function of defending and promoting the position of the ruler, domestically and perhaps also internationally. ${ }^{54}$ About the same time, the Community behind the 'sectarian' Dead Sea Scrolls produced some of its most important documents, all in Hebrew. Their literature, just as the later Psalms of Solomon, can be classified as 'anti-official.' Hence, the Greek language may be considered as yet another propagandistic channel used by Janneus.

There are several observations to be made. First, one notes on Janneus's coins and in literature, the absence of an expression such as 'King of the Jews.' Second, there are no divine images or epithets of Janneus either on coins or in literature. Third, there are no monetary images of the Hasmonean rulers either. These aspects are probably to be explained by the fact YHWH was considered the only King of Israel and who was aniconic. This distinguished them from the Seleucid and many other Hellenistic monarchies. This absence allowed the Hasmoneans to strike up to 24 or even 26 characters (both obverse and reverse) to promote their high status by using more script. Fourth, unlike Mattathias Antigonus (40-37 BCE), Janneus seems to have avoided incising both his titles on the same coin, at least early in his reign. ${ }^{55}$ The same applies to his bullae. This could be due also to the fact that the opposition may have regarded Janneus as a usurper.

In line with the Seleucid tradition, for example, in the neighboring Nabatean kingdom as well as in other contemporary monarchies one finds on their coins-including silver coins-the wording "king" followed by an ethnic denominator, divine images and divine royal epithets, images of both kings and queens, and statues dedicated to various rulers. ${ }^{56}$ Since the institution of the Nabatean kingdom had taken place probably as early as the third century $\mathrm{BCE}$, there is reason to think that the Hasmonean kings were partly influenced by their neighbors. ${ }^{57}$ The peculiar thing is that, unlike on Janneus's coins, one finds no attestation of the (high) priestly title on Nabatean royal coins or inscriptions. Therefore, it is helpful to briefly look elsewhere for a more complete comparison.

\section{Alexander Janneus and Other Hellenistic (High) Priestly Monarchs}

On the one hand, the institution of the Hasmonean high priesthood had its own history rooted in biblical tradition, that had no clear parallels with any Hellenistic monarchy. On the other hand, in time, the Hasmoneans also became kings. In this, they resembled several other Hellenistic rulers. ${ }^{58}$ Again, as stated above, unlike other monarchs, the Hasmoneans did not use their own images or attach to themselves divine epithets or images of their God and more.

53 In support of the original Hebrew Vorlage of 1 Maccabees, see (Darshan 2019, pp. 91-110).

54 On the function of the literature produced by the Hellenistic royal courts, see (Strootman 2010, pp. 30-45). Strootman, p. 35, posits that "the most successful writers were drawn to the major centers of power" and that the production of literature depended to a great extent on the "stability" of the state. We do not know how much new literature was produced under the patronage of Janneus. At least the anti-Hasmonean 'sectarian' scribes, who produced many of the Dead Sea Scrolls, appear to have been quite successful.

55 With regard to Janneus's overstruck coins, Zlotnik (2011) [www.academia.edu], p. 14, made the attractive suggestion that "it can be assumed that the 'priestly' minting that was done on top of the 'royal' minting was not meant to blur or erase the previous minting but to incorporate it in such a way that will display another minting on the coins so both 'royal' and 'priestly' minting" [retrieved from www.academia.edu]. On the coins of Antigonus containing both titles, see (Meshorer 2001, pp. 218-20).

56 For a discussion of Nabatean coinage and royal statues, see (Schwentzel 2013, pp. 183-226). In general, the sources, especially literary, for the Nabatean history, are very scarce. Hence, it is difficult to trace a clear development of this monarchy or explore its various institutional characteristics. On various epithets of the Hellenistic kings, see the detailed study by (Muccioli 2013). Among the royal epithets one finds Theos, Theopator, Soter, Epiphanes, Autokrator, Philopator, and others.

57 On 3rd century BCE papyrus probably mentioning a Nabatean king and Nabatean coins from the third century onward, see (Pearson 2011, pp. 6-15) [https://escholarship.org/uc/item/4dx9g1rj]. Second Maccabees 5:8 mentions the "tyrant" Aretas (about 169/8 BCE). Based on archaeological excavations conducted so far, one notes that a more constant material culture for the Nabateans is found from the end of the second century BCE onward.

58 On various royal models in the ANE and Greece, see (Anagnostou-Laoutides 2017). For a specific discussion, see (Boffo 2015, pp. 41-70; Trampedach 2013, pp. 231-62 (more philosophical)). 
It is not the primary aim here to analyze the various aspects of the offices and powers of Janneus and compare them with those of other rulers. This is the object of a separate study undertaken by the present author. We will only point out to several other local rulers from the Greco-Roman world who exercised similar offices-even down into the first century CE.

Mention here can be made of high priests of Pessinous in Galatia, to whom Strabo refers as $\delta v \vee \alpha ́ \sigma \tau \alpha \iota$ (12.5.3). It was a long traditional dynasty of high priests that survived into the Roman period. In time, they considered themselves kings. ${ }^{59}$ Another person identified by both royal and high priestly titles is Lykomedes of Comana, but who was appointed high priest by Caesar in 47 BCE (Dio Cassius 51.2; Strabo 12.3.38). ${ }^{60}$ Also worth including here are the high priests of Olbia, capital of Rough Cilicia. At first, these archiereis in the line of Teukros, known from at least early third century BCE, are referred to by Strabo as $\delta v v \alpha ́ \sigma \tau \alpha \iota$ (14.5.10). They acted as de facto kings. Much later, in the imperial Roman period, the Teukrid high priests were officially recognized as kings. ${ }^{61}$ Mention here can also be made of the Carian kings with priestly titles, the high priests and kings of Paphos on Cyprus, in Bosporus, and others, whose religious and civil titles are attested in literary, epigraphic and sometimes numismatic evidence. ${ }^{62}$

These Hellenistic high priests exerted important political and administrative control, down to the Roman imperial period. Like Janneus, some of them had armies under their control composed of both ethnic and foreign troops. Thus, Janneus was not the only ruler to officially hold both high priestly and royal offices. In light of the above, before drawing any conclusions, it is still necessary to briefly discuss how Josephus perceived the high priesthood in general, and that of the Hasmoneans in particular.

\section{Josephus, the Hasmonean High Priesthood, and Aaron ${ }^{63}$}

Josephus lived and wrote in the polytheistic and multi-ethnic city of Rome, where Jewish and Christian communities also co-existed. ${ }^{64}$ The imperial cult which had Caesar, the Pontifex Maximus, and his family at the center, was dominant throughout the empire. ${ }^{65}$ One only can guess how Josephus might have reacted at seeing all this. No wonder that in his last work, Against Apion, Josephus is even more ideological with regard to the Jewish high priesthood. ${ }^{66}$

Like other Jewish authors of antiquity, Josephus regarded the high priesthood as superior to kingship. Thus, for example, Philo of Alexandria (ca. 25 BCE-50 CE) reports how King Agrippa I claimed Hasmonean descent and stated how his ancestors regarded the high priesthood as being superior (Legatio 278). This same concept is defended in the Testament of Judah 21.1-4.50. While in both War and Antiquities Josephus seems to approve, at times, the right of the royal authority to appoint a high priest, in his "theocracy" described in Ap. 2.145-189, Josephus apparently leaves no place for a native or foreign king. ${ }^{67}$ That the former Jerusalem temple priest had very high regard for high priestly office can be seen already from Ant. 8.229-230, where King Jeroboam declares himself a high priest (unparalleled in $1 \mathrm{Kgs} \mathrm{12:26-33//2} \mathrm{Chronicles} \mathrm{12),} \mathrm{an} \mathrm{event} \mathrm{which} \mathrm{Josephus} \mathrm{interprets} \mathrm{as} \mathrm{the}$ "beginning of the evils to the Jews".

59 See further, (Welles 1934, nos. 55-61 and pp. 247, 250; Virgilio 1981; Lancellotti 2002, esp. 32-52). See recently the results of new finds including inscriptions in (Tsetskhladze 2019).

60 See (Syme 1995, pp. 144-47, 166-74; Ballesteros-Pastor 2000, pp. 143-50).

61 See (Boffo 1985, pp. 41-47; Gotter 2008, pp. 89-103), who notes that the Teukrid high priests-unlike those in Cappadocia and Pontus-were not appointed by the monarchs.

62 Often scholars speak of 'temple-states'. For various examples down to the imperial Roman period, see (Boffo 1985, pp. 132-33, 259-65; Müller 2000, pp. 519-542; Heinen 2006, pp. 295-304). For similar examples, including from the Roman imperial period, see (Campanile 2006, pp. 523-84 (with previous bibliography); Kirbihler 2008, pp. 107-49; Heller 2017, pp. 1-20).

63 On this aspect, see (Babota 2014, chp. 10).

64 See (Rüpke 2008).

65 See (Witulski 2010; Kolb and Vitale 2016). One of the high positions that was often granted to local high priests and other high standing Hellenistic elites also at the time of Josephus was Philocaesar.

66 See further (Thoma 1989, pp. 196-215; Gussman 2008, pp. 410-18).

67 For a tentative explanation, see (Barclay 2007, pp. 273-75). 
However, it is only later in his list, namely in Ant. 20.225, that the historian states that the institution of the high priesthood goes back to Aaron, whom God chose, and who also had the gift of prophecy (3.192; cf. War 1.68//Ant. 13.299 of Hyrcanus I). No one who is not "of Aaron's blood", be he even a "king", should attain the high priesthood (20.226). ${ }^{68}$ This idealized portrait stands in sharp contrast with his narratives about the Hasmonean high priests. No wonder that not only 1 Maccabees, but Josephus himself, in his narratives, never tries to connect the Hasmonean high priesthood to Aaron.

\section{Conclusions}

The Hellenistic model of high priesthood, combined with civil powers which persisted until Hyrcanus I, no longer sufficed to meet the challenges which the expansion of the Hasmonean state and other developments had brought about. Thus, several reasons led Aristobulus I and especially Janneus to claim the title of king, but they never wanted to give up control of the high priesthood, that for centuries had been the highest distinct national institution.

However, Janneus's position was unprecedented in Jewish history as it adopted many Hellenistic elements. Janneus used several means by which to promote and impose his royal status on his subjects, both Jews and non-Jews, combined with his high priestly office. Some of these means were typical of the biblical tradition; others were imported from the surrounding Hellenistic world. Therefore, for a better understanding of Janneus's status as king and high priest, we should not limit our study to Seleucid, Ptolemaic, or even Nabatean sacral monarchs. It is necessary to also look for other Hellenistic, local, high priestly dynasties which, in time, became royal or acted as de facto kings. At the same time, certain characteristics made the Hasmonean high priestly monarchy unique in the Hellenistic world. This was dictated mainly by theological reasons.

That of Janneus is an example of an institutional clash characterized by the combination of traditional Jewish high priesthood with the Hellenistic model of rule. The Hasmonean kingship, which was consolidated under Alexander Janneus, met with severe obstacles, both internal and external. On the international level, it resulted in almost complete isolation from the surrounding Greco-Roman world, and the subsequent inner Hasmonean struggles brought about Roman intervention. Internally, it provoked a split within the population characterized by repeated strife. Even the separation of the high priesthood from the kingship, following the death of Janneus, was no more sufficient to prevent the slow but steady disintegration of the Hasmonean dynasty. The end-result was that a segment of the population would rather prefer to side with a foreign ruler—or later with Herod the Great—-than with the Hasmoneans. In short, the rule of Janneus was, to a great extent, a unique and, at the same time, very controversial one in the history of Judea.

We have reason to believe that Josephus was well aware of the complexity and controversial aspects surrounding the institution of the Hasmonean kingship under Aristobulus I and especially Janneus. He also was well aware of some highly controversial actions undertaken by Janneus. Still, Josephus never admits these were 'unfit' for Janneus's office of high priest. After all, the Flavian historian himself was a former warrior and priest. He chose not to identify Janneus explicitly as high priest in his narratives, but rather focus mainly on his royal policy. As an alternative, Josephus drafted an idealized list of high priests in Ant. 20.225-245 that became the basis for developing his theocratic model of government, which—he probably hoped—could co-exist under the Roman emperor. ${ }^{69}$

Funding: This research received no external funding.

Acknowledgments: I thank Chris Seeman for inviting me to contribute to this volume and for helping me with my English. Any remaining errors or imprecisions are, of course, my sole responsibility.

Conflicts of Interest: The author declares no conflict of interest.

68 See (Gussman 2008, pp. 278-80).

69 See here also (Gussman 2008, pp. 320-24). 


\section{References}

Anagnostou-Laoutides, Eva. 2017. In the Garden of the Gods: Models of Kingship from the Sumerians to the Seleucids. New York: Routledge.

Ariel, Donald T. 1982. A Survey of Coin Finds in Jerusalem (Until the End of the Byzantine Period). Liber Annuus 32: 273-26.

Atkinson, Kenneth. 2016. A History of the Hasmonean State: Josephus and Beyond. JCTCRS 23. London: Bloomsburry T\&T Clark.

Atkinson, Kenneth. 2018. The Hasmoneans and their Neighbors: New Historical Reconstructions from the Dead Sea Scrolls and Classical Sources. London: Bloomsburry T\&T Clark.

Babota, Vasile. 2014. The Institution of the Hasmonean High Priesthood. JSJSup 165. Leiden: Brill.

Babota, Vasile. 2020. Forthcoming. The Sons of Zadok, Alexander Janneus, and the Book of Ezekiel. Revue de Qumran.

Babota, Vasile. forthcoming. In Search of the Origins of the Pharisees. In Jesus and the Pharisees: An Interdisciplinary Reappraisal. Edited by Amy-Jill Levine and Joseph Sievers. Grand Rapids: Wm. B. Eerdmans.

Ballesteros-Pastor, Luis. 2000. El Santuario de Comana Póntica. Apuntes para su historia. Arys 3: 143-50.

Barclay, John M. G. 2007. Against Apion. In Flavius Josephus: Translation and Commentary. Edited by Steve Mason. Leiden: Brill, vol. 10.

Berrin, Shani L. 2004. The Pesher Nahum Scroll from Qumran: An Exegetical Study of 4Q169. Leiden: Brill.

Berthelot, Katell. 2018. In Search of the Promised Land? The Hasmonean Dynasty Between Biblical Models and Hellenistic Diplomacy. Translated by Margaret Rigaud. Göttingen: Vandenhoeck \& Ruprecht.

Boffo, Laura. 1985. I re ellenistici e i centri religiosi dell'Asia Minore. Pubblicazioni della facoltà di lettere e filosofia dell'Università di Pavia 37. Firenze: La Nuova Italia.

Boffo, Laura. 2015. Il mondo ellenistico degli imperi sopra-locali e delle dinastie regionali: Seleucidi e asmonei. Ricerche Storico Bibbliche 27: 41-70.

de Calataÿ, François, and Catharine C. Lorber. 2011. The Pattern of Royal Epithets on Hellenistic Coinages. In More Than Men, Less Than Gods: Studies on Royal Cult and Imperial Worship. Edited by Panagiotis P. Iossif, Andrzej S. Chankowski and Catharine C. Lorber. Studia Hellenistica 51. Leuven: Peeters, pp. 417-55.

Campanile, Maria Domitilla. 2006. Sommi sacerdoti, asiarchi e culto imperiale: Un aggiornamento. In Studi Ellenistici, XIX. Edited by Biagio Virgilio. Pisa: Giardini Editori e Stampatori, pp. 523-84.

Chaniotis, Angelos. 2005. War in the Hellenistic World: A Social and Cultural History. Oxford: Blackwell.

Collins, John J. 2010. The Scepter and the Star: Messianism in Light of the Dead Sea Scrolls, 2nd ed. Grand Rapids: Wm. B. Eerdmans.

Dabrowa, Edward. 2010. The Hasmoneans and Their State: A Study in History, Ideology, and the Institutions. Electrum 16. Krakow: Jagiellonian University Press.

Darshan, Guy. 2019. The Original Language of 1 Maccabees: A Reexamination. Biblische Notizen (NF) 182: 91-110.

Doudna, Gregory L. 2011. Allusions to the End of the Hasmonean Dynasty in Pesher Nahum (4Q169). In The Mermaid and the Partridge: Essays from the Copenhagen Conference on Revising Texts from Cave Four. Edited by George J. Brooke and Jesper Høgenhaven. STDJ 96. Leiden: Brill, pp. 259-78.

Eckhardt, Benedikt. 2013. Ethnos und Herrschaft: Politische Figurationen judäischer Identität von Antiochos III. bis Herodes I. SJ 72. Berlin: De Gruyter.

Ehling, Kay. 2008. Untersuchungen zur Geschichte der späten Seleukiden (164-63 v. Chr.): Vom Tode des Antiochs IV. bis zur Einrichtung der Provinz Syria unter Pompeius. Historia-Einzelschriften 196. Stuttgart: Steiner.

Feldman, Louis H. 1994. Josephus' Portrayal of the Hasmoneans Compared with 1 Maccabees. In Josephus and the History of the Greco-Roman Period. Essays in Memory of Morton Smith. Edited by Fausto Parente and Joseph Sievers. Studia post-biblica 41. Leiden: Brill, pp. 41-68.

Goodman, Martin. 1999. The Pilgrimage Economy of Jerusalem in the Second Temple Period. In Jerusalem: Its Sanctity and Centrality to Judaism, Christianity, and Islam. Edited by Lee I. Levine. New York: Continuum, pp. 69-76.

Gotter, Ulrich. 2008. Priests-Dynasts-Kings. Temples and Secular Rule in Asia Minor. In Practitioners of the Divine: Greek Priests and Religious Officials from Homer to Heliodorus. Edited by Beate Dignas and Kai Trampedach. Hellenic Studies 30. Cambridge: Harvard University Press, pp. 89-103.

Griffith, Guy T. 1935. The Mercenaries of the Hellenistic World. Cambridge: The University Press. 
Gussman, Oliver. 2008. Das Priesterverständnis des Flavius Josephus. TSAJ 124. Tübingen: Mohr/Siebeck.

Hanan, Eshel. 2008. The Dead Sea Scrolls and the Hasmonean State. Jerusalem: Yad Ben-Zvi.

Heinen, Heinz. 2006. Vom hellenistischen Osten zum römischen Westen. Ausgewählte Schriften zur Alten Geschichte. Historia Einzelschriften 191. Stuttgart: Franz Steiner.

Heller, Anna. 2017. Priesthoods and Civic Ideology. In Empire and Religion: Religious Change in Greek Cities under Roman Rule. Edited by Elena Muñiz Grijalvo. Impact of Empire 25. Leiden: Brill, pp. 1-20.

Hendin, David. 2008. Numismatic Expressions of Hasmonean Sovereignty. Israel Numismatic Journal 16: 76-91.

Hendin, David, and Ilan Shachar. 2008. The Identity of YNTN on Hasmonean Overstruck Coins and the Chronology of the Alexander Jannaeus Type. Israel Numismatic Research 3: 87-94.

Van Henten, Jan W. 2014. Judean Antiquities 15. In Flavius Josephus: Translation and Commentary. Edited by Steve Mason. Leiden: Brill, vol. 7B.

Hoover, Oliver D. 2003. The Seleucid Coinage of John Hyrcanus I: The Transformation of a Dynastic Symbol in Hellenistic Judaea. American Journal of Numismatics 15: 29-40.

Hoover, Oliver D. 2009. Handbook of Syrian Coins. Royal and Civic Issues: Fourth to First Centuries BC. Handbook of Greek Coinage Series 9; Lancaster: Classical Numismatic Group.

Hoover, Oliver D. 2010. Handbook of Coins of the Southern Levant: Phoenicia, Southern Koile Syria (including Judaea), and Arabia, Fifth to First Centuries BC. Handbook of Greek Coinage Series 10; Lancaster: Classical Numismatic Group.

Hübner, Ulrich. 2005. Tradition und Innovation: Die Münzprägungen der Hasmonäer des 2. Und 1. Jahrhunderts v. Chr. als Massenmedien. In Medien im antiken Palästina: Materielle Kommunikation und Medialität als Thema der Palästinaarchäologie. Edited by Frevel Christian. FAT 2/10. Tübingen: Mohr Siebeck, pp. 171-87.

Kerkeslager, Allen. 1998. Jewish Pilgrimage and Jewish Identity in Hellenistic and Early Roman Egypt. In Pilgrimage and Holy Space in Late Antique Egypt. Edited by David Frankfurter. RGRW 134. Leiden: Brill, pp. 99-225.

Kirbihler, François. 2008. Les grand-prêtres d'Éphèse: Aspects institutionnels et sociaux de l'Asiarchie. In Pathways to Power: Civic Elites in the Eastern Part of the Roman Empire. Edited by Athanasios D. Rizakis and Francesco Camia. Tripodes 6. Atene: Scuola Archeologica Italiana di Atene, pp. 107-49.

Kolb, Anne, and Marco Vitale, eds. 2016. Kaiserkult in den Provinzen des Römischen Reiches: Organisation, Kommunikation und Reprasentation. Berlin: De Gruyter.

van der Kooij, Arie. 2012. The Claim of Maccabean Leadership and the Use of Scripture. In Jewish Identity and Politics between the Maccabees and Bar Kokhba: Groups, Normativity, and Rituals. JSJSup 155. Leiden: Brill, pp. 29-49.

Lancellotti, Maria Grazia. 2002. Attis Between Myth and History: King, Priest and God. RG-RW 149. Leiden: Brill.

Lapin, Hayim. 2018. Feeding the Jerusalem Temple: Cult, Hinterland and Economy in First Century Palestine. Journal of Ancient Judaism 8: 409-53. [CrossRef]

Laqueur, Richard. 1920. Der jüdische Historiker Flavius Josephus: Ein biographischer Versuch auf neuer quellenkritischer Grundlage. Giessen: Munchow.

Launey, Marcel. 1950. Recherches sur les Armées Hellénistiques. 2 vols, BEFAR 169. Paris: E. de Boccard.

Loman, Pasi. 2005. Mercenaries, Their Women, and Colonisation. Klio 87: 346-65. [CrossRef]

Ma, John. 2003. Kings. In A Companion to the Hellenistic World. Edited by Andrew Erskine. BCAW. Malden: Wiley-Blackwell, pp. 177-95.

Macurdy, Grace H. 2000. Hellenistic Queens: A Study of Woman-Power in Macedonia, Seleucid Syria, and Ptolemaic Egypt. JHUSA 14. Baltimore: The John Hopkins Press. First published 1932.

Marcus, Ralph. 1957. Josephus: Jewish Antiquities, Books XII-XIV, LCL. Cambridge: Harvard University Press.

Marcus, Ralph. 1963. Josephus: Jewish Antiquities, Books XV-XVII, LCL. Cambridge: Harvard University Press.

Mason, Steve. 2001. Life of Josephus. In Flavius Josephus: Translation and Commentary. Edited by Steve Mason. Leiden: Brill, vol. 9.

Mason, Steve. 2016. Josephus's Judean War. In A Companion to Josephus. Edited by Honora H. Chapman and Zuleika Rodgers. BCAW. Malden: Wiley-Blackwell, pp. 11-35.

Mendels, Doron. 2005. The Formation of an Historical Canon of the Greco-Roman Period: From the Beginnings to Josephus. In Josephus and Jewish History in Flavian Rome and Beyond. Edited by Gaia Lembi and Joseph Sievers. JSJSup 104. Leiden: Brill, pp. 3-19. 
Meshorer, Ya'akov. 2001. A Treasury of Jewish Coins: From the Persian Period to Bar Kokhba. Jerusalem: Yad Ben Zvi Press.

Mitchell, Lynette G. 2012. The Women of Ruling Families in Archaic and Classical Greece. Classical Quarterly 62: 1-21. [CrossRef]

Muccioli, Federicomaria. 2013. Gli Epiteti Ufficiali dei re Ellenistici. Historia-ZAG 224. Stuttgart: Franz Steiner Verlag.

Müller, Helmut. 2000. Der Hellenistische Archiereus. Chiron 30: 519-42.

Nodet, Étienne. 2005. La Crise Maccabèeenne: Historiographie Juive et Traditions Bibliques. Josèphe et Son Temps 5. Paris: Cerf.

Pearson, Jeffrey E. 2011. Contextualizing the Nabataeans: A Critical Reassessment of their History and Material Culture. Ph.D. dissertation, UC Berkeley, Berkeley, CA, USA; pp. 6-15. Available online: https://escholarship. org/uc/item/4dx9g1rj (accessed on 10 January 2020).

Piotrkowski, Meron M. 2015. Josephus on Hasmonean Kingship. The Example of Aristobulus I and Alexander Jannaeus. In Antimonarchic Discourse in Antiquity. Edited by Henning Börm. SAM 3. Stuttgart: Franz Steiner Verlag, pp. 249-68.

Pomykala, Kenneth E. 1995. The Davidic Dynasty Tradition in Early Judaism: Its History and Significance for Messianism. SBL.EJL 7. Atlanta: Scholars.

Rajak, Tessa. 1987. Josephus and Justus of Tiberias. In Josephus, Judaism, and Christianity. Edited by Louis H. Feldman and Gohei Hata. Leiden: Brill, pp. 103-26.

Regev, Eyal. 2013. The Hasmoneans: Ideology, Archaeology, Identity. JAJSup 10. Göttingen: Vandenhoeck \& Ruprecht. Rüpke, Jörg. 2008. Fasti Sacerdotum: A Prosopography of Pagan, Jewish, and Christian Religious Officials in the City of Rome, 300 BC to AD 499. Translated by David M. B. Richardson. Oxford: University Press.

Schiffman, Lawrence H. 1999. Priestly and Levitical Gifts. In The Provo International Conference on the Dead Sea Scrolls: Technological Innovations, New Texts, and Reformulated Issues. Edited by Donald W. Parry and Eugene Ch. Ulrich. STDJ 30. Leiden: Brill, pp. 480-96.

Schiffman, Lawrence H. 2010. Qumran and Jerusalem: Studies in the Dead Sea Scrolls and the History of Judaism. SDSSRL. Grand Rapids: Wm. B. Eerdmans.

Schwartz, Daniel R. 1983. Josephus and Nicolaus on the Pharisees. Journal for the Study of Judaism 14: 157-71. [CrossRef]

Schwartz, Daniel R. 2016. Many Sources but a Single Author: Josephus's Jewish Antiquities. In A Companion to Josephus. Edited by Honora H. Chapman and Zuleika Rodgers. BCAW. Malden: Wiley-Blackwell, pp. 36-58.

Schwentzel, Christian-Georges. 2013. Juifs et Nabatéens: Les Monarchies Ethniques du Proche-Orient Hellénistique et Romain. Collection «Histoire». Rennes: Presses Universitaires de Rennes.

Seeman, Chris. 2013. Rome and Judea in Transition: Hasmonean Relations with the Roman Republic and the Evolution of the High Priesthood. AUS.TR 325. New York: Peter Lang.

Shachar, Ilan. 2004. The Historical and Numismatic Significance of Alexander Jannaeus's Later Coinage as Found in Archaeological Excavations. Palestine Exploration Quarterly 136: 5-33. [CrossRef]

Sharon, Nadav. 2017. Judea Under Roman Domination: The First Generation of Statelessness and Its Legacy. SBL.EJIL 46. Atlanta: SBL.

Shatzman, Israel. 1991. The Armies of the Hasmonaeans and Herod: From Hellenistic to Roman Frameworks. TSAJ 25. Tübingen: Mohr/Siebeck.

Sievers, Joseph. 1989. The Role of Women in the Hasmonean Dynasty. In Josephus, the Bible, and History. Edited by Louis H. Feldman and Gohei Hata. Leiden: Brill, pp. 134-40.

Stern, Menahem. 1971. Nicolaus of Damascus as a Source of Jewish History in the Herodian and Hasmonean Age. In Studies in Bible and Jewish History Dedicated to the Memory of Jacob Liver. Edited by Benjamin Uffenheimer. Tel Aviv: Tel Aviv University, pp. 375-94. (In Hebrew)

Stern, Menahem. 1974. Greek and Latin Authors on Jews and Judaism, I: From Herodotus to Plutarch. Jerusalem: The Israel Academy of Sciences and Humanities.

Stevens, Marty E. 2006. Temples, Tithes, and Taxes: The Temple and the Economic Life of Ancient Israel. Peabody: Hendrickson Publishers.

Strootman, Rolf. 2010. Literature and the Kings. In A Companion to the Hellenistic Literature. BCAW. Edited by James J. Clauss and Martine Cuypers. Malden: Wiley-Blackwell, pp. 30-45.

Syme, Ronald. 1995. Anatolica: Studies in Strabo. Edited by Anthony Birley. Oxford: Clarendon Press. 
Tal, Ilan. 1987. The Greek Names of the Hasmoneans. Jewish Quarterly Review 78: 1-20.

Thackeray, Henry St. J. 1927. Josephus: The Jewish War, Books I-III. LCL. Cambridge: Harvard University Press.

Thoma, Clemens. 1989. The High Priesthood in the Judgment of Josephus. In Josephus, the Bible and History. Edited by Louis H. Feldman and Gohei Hata. Detroit: Wayne State University Press, pp. 196-215.

Toher, Mark. 2017. Nicolaus of Damascus: The Life of Augustus and the Autobiography: Edited with Introduction, Translations and Historical Commentary. Cambridge: Cambridge University.

Trampedach, Kai. 2013. Between Hellenistic Monarchy and Jewish Theocracy. In The Splendors and Miseries of Ruling Alone Encounters with Monarchy from Archaic Greece to the Hellenistic Mediterranean. Edited by Nino Luraghi. Studies in Ancient Monarchy 1. Stuttgart: Franz Steiner Verlag, pp. 231-62.

Tsetskhladze, Gocha R., ed. 2019. Pessinus and Its Regional Setting, I-II. Colloquia Antiqua 21-22. Leuven: Peeters. VanderKam, James C. 2004. From Joshua to Caiaphas: High Priests after the Exile. Minneapolis: Fortress Press.

Virgilio, Biagio. 1981. Il «Tempio Stato» di Pessinunte fra Pergamo e Roma nel II-I secolo a.C. (C.B. Welles, RC 55-61). Pisa: Giardini.

Wacholder, Ben Zion. 1962. Nicolaus of Damascus. UCPH 75. Berkeley: University of California.

Wacholder, Ben Zion. 1974. Eupolemus: A Stuty of Judaeo-Greek Literature. MHUC 3. Cincinnati: Jewish Institute of Religion.

Wacholder, Ben Zion. 1989. Josephus and Nicolaus of Damascus. In Josephus, the Bible, and History. Edited by Louis H. Feldman and Gohei Hata. Detroit: Wayne State University Press, pp. 152-72.

Welles, Charles B. 1934. Royal Correspondence in the Hellenistic Period. New Haven: Yale University Press.

Witulski, Thomas. 2010. Kaiserkult in Kleinasien: Die Entwicklung der Kultisch-religiösen Kaiserverehrung in der Römischen Provinz Asia von Augustus Bis Antoninus Pius, 2nd ed. NTOA 63. Göttingen: Vandenhoeck \& Ruprecht.

Zlotnik, Yehoshua. 2011. Alexander Jannaeus' Coins and Their Dates. 1-18. Available online: www.academia.edu (accessed on 10 January 2020).

Zollschan, Linda. 2017. Rome and Judaea: International Law Relations, 174-100 BCE. London: Routledge.

(C) 2020 by the author. Licensee MDPI, Basel, Switzerland. This article is an open access article distributed under the terms and conditions of the Creative Commons Attribution (CC BY) license (http://creativecommons.org/licenses/by/4.0/). 